\title{
STUDIES
}

\section{Migration to Germany: Structures, processes, and discourses}

Birgit Glorius Taking the example of Germany as a demoChemnitz University of graphically ageing country, this paper starts

Technology, with the assumption that international migra-

Germany tion and a sound long-term integration of in-

E-mail: ternational migrants are crucial for sustainable

birgit.glorius@phil.tu-chemnitz.de population development. However, owing to the complexity of migration motives and individual migration decisions on the one hand, and the multidimensionality of external causes for migration and political regulations aiming to steer migration, on the other hand, the demand and supply side of migration can vary considerably. This paper reflects on recent important migratory movements to Germany (notably inner-European mobility after the expansion of the European Union (EU), and student and refugee migration in the wake of the economic and financial crisis) and concomitant policy changes. Two main arguments are made along these empirical observations: first, the effective regulation of international migration in Germany as in any other European country can only be derived by harmonising migration regulations on a supranational level, and second, the issue of migration and its regulation touch on crucial topics in European and national public discourse such as the stabilisation of individual and group identities in turbulent times. Thus, as

Keywords: per the arguments put forth by this study, in European integration, order to solve actual imbalances in the EuroGermany, pean migration and asylum system, questions integration, on social justice and common European valmigration, ues will need to be addressed throughout the migration regulation European countries and at the EU level.

Regional Statistics, Vol. 8. No. 1. 2018: 3-28; DOI: 10.15196/RS080101 


\section{Introduction}

Like most European societies, the German population went through a demographic transition decades ago, characterised - among other indicators - by declining fertility levels and late births (Van de Kaa 1987, 2001). For a long time, the natural population balance has been negative and the mean age has been increasing, raising concerns about labour force shortages and the lack of sustainability of German social systems. Regarding the population development in Germany since 1990, it is clear that migration is the most important factor in terms of population development, and it is the most variable factor to boot. Declining birth rates and rising death rates amounted to negative natural balances for years, while the migration balance was mostly positive, albeit with high variations: while net gains augmented 400,000 in 1991-1993, the migration balance shrank drastically thereafter until it reached a first minimum of 47,098 in 1998. Since then, net gains ranged between 150,000 and 200,000 for some years, and decreased sharply resulting in net losses in 2008 and 2009. Since 2010, the migration balance has been positive again, with a yearly increase of around 100,000, with the exception of plus 1.1 million in the peak year 2015, when around 2 million people moved to Germany. Among them were almost 1 million asylum seekers. Calculated as an average over the whole observation period 1991-2015, the natural balance was around minus 125,000 p.a., while the migration balance was around 295,000 p.a. Based on the assumption of continued low fertility levels and high longevity, the stability of the German population in terms of age group and population of working age will depend on a continued positive migration balance of between 100,000 and 200,000 persons per year (Statistisches Bundesamt 2015).

\section{Population development in Germany - births, deaths, immigration, and emigration}

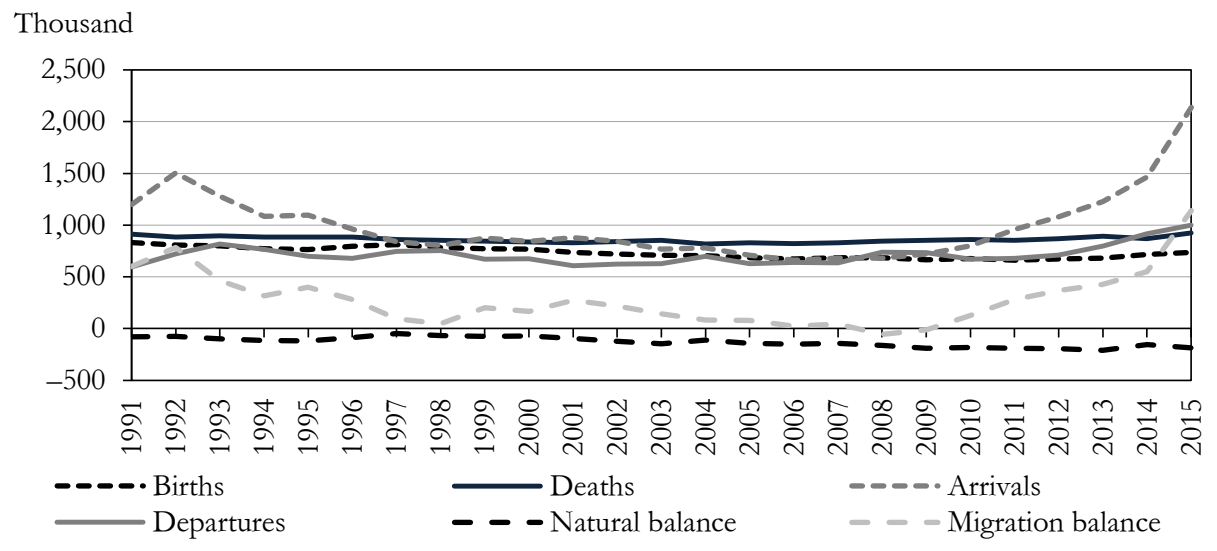

Source: Data of the Statistical Office of the Federal Republic of Germany.

Regional Statistics, Vol. 8. No. 1. 2018: 3-28; DOI: 10.15196/RS080101 
Taking the example of Germany, this study explores how migration can support the sustainable population development of a country. Thus, key questions to be explored are, how (and if) the quantity and quality of migratory streams can be regulated, how actual migration processes and the presence of migrants in a country influence policy development and the development of public opinion about migration, integration and related issues.

The study tackles this issue by exploring migration to and from Germany within the wider context of European mobility. Focusing on the post-EU-enlargement period until today, it deals with the main migration flows and their drivers as well as concomitant policy developments and public discourses about migration. Following the introduction, chapter two reflects the main strands of research on German postwar migration and relates it to the wider European context. Chapter three focuses on major mobility transformations since the 2000 s, notably on the migratory changes following the EU enlargement of 2004 and 2007, the expansion of student mobility and the increasing migration to Germany as a reaction to the European financial crisis. The chapter not only describes those migratory processes, but also elaborates on the development of policies and public discourses on migration. Chapter four is devoted to the recent large-scale arrival of asylum-seekers in Germany and the consequences of integration management, policy development and public opinion. This paper closes with a final reflection on the general effects of migration on demographic, economic and societal development in Germany, and provides an outlook on issues in this context that need to be tackled at a supra-national level.

\section{Main topics and developments in migration and migration research since the Second World War}

As Europe is embedded in the global landscape of migration, changes on a global level affect mobility to and within the continent considerably. At the state level, economic transformations or changes in political regulation schemes translate into changing mobility patterns which also affect neighbouring states or Europe as a whole. In the historical development of migration in Europe after the Second World War, several stages that have influenced European nation states to a varying extent can be identified. For Germany, the repatriation of ethnic Germans had considerable effects in quantitative terms as well as in terms of the social fabric of the population. Between 1950 and 1999, around 2 million ethnic Germans from Central and Eastern Europe migrated to Germany under the 'Spätaussiedler' (German resettlers') migration scheme (Worbs et al. 2013)..$^{1}$ Although they received German citizenship immediately and were supported financially, a considerable number of inte-

\footnotetext{
${ }^{1}$ This movement continued and even increased after the end of the Cold War. Until 2012, around 4.5 million ethnic Germans remigrated to Germany (Worbs et al. 2013, p. 28.).
}

Regional Statistics, Vol. 8. No. 1. 2018: 3-28; DOI: 10.15196/RS080101 
gration and identity problems were noted, especially in the later repatriation waves and partly among the second generation (Kiel 2009, Steiz 2011).

In other European countries, the decolonisation process fuelled immigration. Between 1940 and 1975, around 7 million migrants moved from the former colonies to the United Kingdom, France, Italy, Portugal, the Netherlands, and Belgium (Bade 2000, p. 307.). Consequently, those countries were confronted with questions of ethnic and religious diversity, discrimination and racism, and models of incorporation at a fairly early stage (Balibar-Wallerstein 1990, Entzinger 1998, Pilkington 1988, Solomos 1993).

During the Cold War, migration patterns in Eastern and Western Europe differed considerably. In parts of Western Europe and the Nordic countries, labour migration schemes for the recruitment of so-called 'guest workers' were developed since the 1950s, in order to support rapid industrial developments during those times. Around 15 million labour migrants arrived between the 1950s and 1970s, mainly from Mediterranean Europe, and also from the Maghreb countries ${ }^{2}$ and Turkey, based on bilateral recruitment schemes (Hammar 1984). Those movements were planned on a temporary base. However, as an effect of economic changes and an unintended consequence of regulatory changes following the oil price crisis, a significant share of temporary migrants became permanent settlers, which significantly changed the social fabric of the societies concerned. In the case of Germany (Federal Republic of Germany [FRG]), the recruitment of guest workers is said to have facilitated the social mobility of indigenous workers, as they took on the least prestigious positions in the labour market (Heckmann 1981). Up until today, guest workers and their descendants account for the largest share of the population with a migration background in Germany, which counteracts the long-held opinion that Germany is a non-immigrant country. In addition, in the German Democratic Republic (GDR), labour migration schemes were developed since the 1950s. Mainly labour migrants from other European socialist countries, but later also from Cuba, Mozambique and Vietnam, were recruited to either work in the big industrial plants in the GDR or receive vocational education. With the breakdown of the socialist regime, most of those labour migrants were forced to return to their home countries (Elsner-Elsner 1994, Jasper 1991).

After the end of the Cold War, a new migration regime came into practice, as citizens from Central and Eastern European countries had the opportunity to leave their countries without travel restrictions. The economic and wage-gaps between East and West were decisive factors for rapidly increasing East-West migration, but legal work opportunities remained scarce (Cyrus 1994, Morokvasic-de Tinguy 1993). Based on bilateral agreements, a significant number of labour migrants headed to Germany and Austria for legal short-term employment in agriculture and con-

${ }^{2}$ Algeria, Morocco, Mauritania, Tunisia, and Libya.

Regional Statistics, Vol. 8. No. 1. 2018: 3-28; DOI: 10.15196/RS080101 
struction; in parallel, irregular labour migrants mostly found work in construction, homes, or as day labourers. The latter group, in particular, often experienced precarious working and living conditions (Düvell 2004, Hofer 1992, Irek 1998).

The EU expansion of 2004 and 2007 again changed the migratory schemes, as the onset of freedom of mobility for the new EU countries offered new forms of mobility and new destinations. Especially the United Kingdom which immediately opened its labour market to citizens of the new EU members, received large numbers of labour migrants, while traditional labour-migration schemes such as the seasonal labour migration scheme between Poland and Germany declined to do so. ${ }^{3}$ Many of the 'new' migrants developed sophisticated mechanisms of travelling back and forth, facilitated by cheap airlines and easy border-crossings, and thus established transnational and translocal livelihood (Apsite 2010, Drinkwater et al. 2009, Glorius et al. 2013).

In this context, the question of economic consequences gained importance with regard to the source countries of East-West migration. While the positive monetary effects through remittances were out of the question, there was rising concern for the human capital loss owing to the selectivity of migration, which included a large number of young university graduates who had left their countries of origin. Among other aspects, there was a critical reflection of the phenomenon wherein many of those young graduates entered low-skilled positions in the destination countries' labour markets and thus experienced brain devaluation (Currie 2007).

Meanwhile, owing to relevant changes in the migratory streams, return migration and re-gain of human capital are often debated issues in Central and Eastern European countries (Markova 2010, Mayr-Peri 2008). Research on this subject deals with re-integration of return migrants in the home labour markets, transfer of knowledge and skills, and positive effects for the destination regions of return migration which are usually the capital cities and larger agglomerations (Klagge-Klein-Hitpass 2010, Nadler et al. 2016). This also applies to educational migration. A number of empirical studies have examined the value of studies abroad and the mechanisms of human capital transfer to the Central and Eastern European source countries and stressed the value of transcultural competences and the ability to 'translate' knowledge acquired abroad to the home countries' specifics, practiced by those young returnees (Baláž-Williams 2004, Teichler-Janson 2007, Wolfeil 2013). Recent studies on return migration and its development emphasise the role of social innovation, that is, innovations beyond economic capital, and their contribution to social and economic changes (Grabowska-Engbersen 2016, Grabowska et al. 2017).

\footnotetext{
${ }^{3}$ While Polish seasonal workers, in the year of Poland's EU integration in 2004, had the highest share of 86 per cent of the total of 333,690 seasonal workers in Germany, their share dropped quickly to 60 per cent in 2010 which was the last year that seasonal work permits were issued to Polish citizens (BMI 2014).
}

Regional Statistics, Vol. 8. No. 1. 2018: 3-28; DOI: 10.15196/RS080101 


\section{Migration to Germany within an enlarged European Union: policies, processes, and discourses}

\section{Development of migration policies}

In the wake of the EU expansions of 2004 and 2007, many of the EU15 countries ${ }^{4}$ apprehended negative consequences owing to increasing East-West migration, especially where Austria and Germany were concerned, as both countries received significant migration flows from Central and Eastern Europe after 1989/90. As a reaction to these concerns, the implementation of free movement of labour was organised over several stages. During a transitional period of five years, EU members could keep their labour markets closed for migrants from new member states. This period could be expanded to up to seven years, if a 'serious disorder of national labour markets' was claimed (Lachmayer-Bauer 2008, p. 693.). While Ireland, Sweden and the United Kingdom immediately opened their labour markets to the new EU members of 2004, most of the other EU countries liberated labour market access after five years. Austria, Belgium, Denmark and Germany made use of the full duration of seven years before granting full freedom of movement to the new EU citizens from Central and Eastern Europe, which was 1 May 2011 for the new EU members of 2004, and 1 January 2014 for the new EU members of 2007 (Bulgaria and Romania).

That is, Germany opted for the most restrictive migration scheme, meaning that until 2011, citizens from new EU countries were treated like third country citizens: the recruitment stop ${ }^{5}$ which has been in place since 1973, strongly restricted labour migration. Practically, only labour migrants for low qualification jobs were granted labour market access on a temporary basis (for example, in agriculture or construction). The new migration law of 2004 introduced new regulations for the labour market access of highly skilled or self-employed migrants, but the criteria for labour market access were high, and therefore, only a small number of candidates made use of those new regulations. ${ }^{6}$

In the following years, the criteria for labour market access were alleviated. For example, the income criteria which highly qualified migrants had to meet in order to achieve a residence permit were lowered, and priority checks were partly abolished (BMI 2008, p. 89.). New labour market access rules were put in force for foreign students who graduated from any German university. They could now apply for a 12-months residence permit for the purpose of job search after graduation, which was extended to 18 months in 2012 (\$16, 4 AufenthG). In addition, the ratifi-

\footnotetext{
${ }^{4}$ EU15: Austria, Belgium, Denmark, Finland, France, Germany, Greece, Ireland, Italy, Luxembourg, the Netherlands, Portugal, Spain, Sweden, the United Kingdom.

${ }^{5}$ For the recruitment stop regulation (Anwerbestoppausnahmeverordnung [ASAV]), see http://www.aufenthaltstitel.de/asav.html

${ }^{6}$ In 2006, 10,800 work permits under the new schemes were issued to highly qualified candidates (specialists, academics, managers, etc.), while 320,000 work permits were issued under the conventional scheme for seasonal workers, fairground helpers, or contract workers in construction (see BMI 2008, p. 68.).
}

Regional Statistics, Vol. 8. No. 1. 2018: 3-28; DOI: 10.15196/RS080101 
cation of the EU Services Directive of 2006 (to realise the full potential of services markets in Europe by removing legal and administrative barriers to trade) and the introduction of the Blue Card EU7 in 2012 were important innovations with respect to the German migration and residence regulations.

The development of migration and labour market regulations can be interpreted as a paradigmatic shift in German migration politics, turning away from a general migration ban towards a neo-liberal approach of labour migration management. This change was driven by the effects of demographic change and accompanied by the development of a common European migration regulation. Thus, Germany entered a new stage of migration regulation which can be characterized as a 'battle for the brains' (Doomernik-Koslowski-Thränhardt 2009). The following chapters reveal how those changing migration schemes affected mobility processes between Germany and other EU countries.

\section{Migration to Germany and labour market integration after EU enlargement}

Especially in the case of the Central and Eastern European accession countries of 2004 (EU8) $^{8}$ and 2007 (EU2) $^{9}$, temporary migration dominated for many years, and therefore, relatively low migration gains were recorded (see Figure 2). This can be explained by the continued restricted accessibility of the German labour market which mainly allowed temporary employment, for example, seasonal Portugal and Spain (EU4), migration losses were recorded until 2009, partly owing to the return of guestworker migrants from the 1960s and 1970s who had reached retirement age.

The increasing number of immigrants from the EU countries to Germany since 2009 can be explained by the economic and financial crisis that affected many European countries severely, while Germany's economy remained stable. Consequently, especially residents of those Southern European countries that were severely touched by the crisis, started moving to Germany in growing numbers. Furthermore, there was also an 'evasive' movement of immigrants from the new EU countries who used to work in other EU countries but had lost their jobs owing to the economic crisis. It is estimated that around three quarters of the immigration increase in Germany can be attributed to such movements (Bertoli-Brücker-Fernández-Huertas Moraga 2013). The fact that the EU8 countries gained full freedom of movement in May 2011 contributed to this increase, as did the EU integration of Romania and Bulgaria in 2007. By the accession year 2007, the number of arrivals from the EU2 countries had doubled and since then has increased annually by 10-20 per cent. However, 2010, 2011 and 2014 witnessed an increase of around 30 per cent compared to the previous year.

\footnotetext{
${ }^{7}$ For more information, see http://www.bluecard-eu.de

${ }^{8}$ EU8: Czech Republic, Estonia, Hungary, Latvia, Lithuania, Poland, Slovakia, Slovenia.

${ }_{9}$ EU2: Bulgaria, Romania.
}

Regional Statistics, Vol. 8. No. 1. 2018: 3-28; DOI: 10.15196/RS080101 
Migration of EU8, EU4, and EU2 citizens to/from Germany

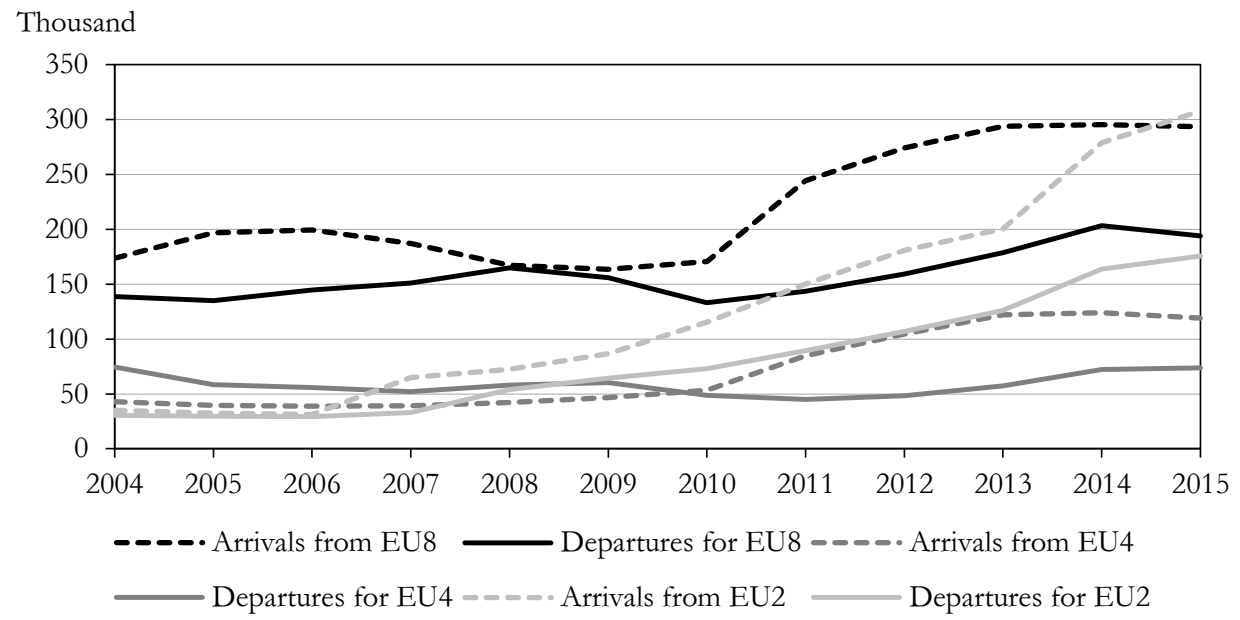

Note: EU8 countries: Czech Republic, Estonia, Hungary, Latvia, Lithuania, Poland, Slovakia, Slovenia; EU4 countries: Greece, Italy, Portugal, Spain; EU2 countries: Bulgaria, Romania.

Source: Data of the Federal Ministry of the Interior and the Federal Office for Migration and Refugees (Germany).

Considering migrants' qualifications and their labour market integration, the data show a higher rate of migrants from the 'old' EU countries (EU1410) aged 25-44 that have undergone tertiary education (46\%) in comparison with the German population of the same age (18\%). Immigrants from the EU8 and EU2 countries also had a higher academic quota of around 21 per cent (SVR 2013, p. 100.). Thus, we can summarise that Germany generally benefits from European free movement in terms of gaining a qualified labour force. However, the share of unskilled immigrants is also higher than in the resident population, reaching 21 per cent among EU14 25-44-year-old migrants, 23 per cent among EU8 migrants and 40 per cent among EU2 migrants.

The employment figures for all migrants from the 'new' EU countries (EU8, EU2) and from the Southern European countries (EU4) have significantly increased in recent years (see Figure 3). The abolition of labour market restrictions is clearly visible among the new EU members: employment of migrants from EU8 countries grew by 44 per cent in 2011 compared to the previous year, while employment from EU2 countries rose by 52 per cent between 2013 and 2014. The least significant growth was observed for migrants from the EU4 countries, but their employment was already at the highest among the three groups considered (BA 2014).

${ }^{10}$ EU15 excluding Germany.

Regional Statistics, Vol. 8. No. 1. 2018: 3-28; DOI: 10.15196/RS080101 
Figure 3

EU8, EU4, and EU2 citizens in the labour market of Germany

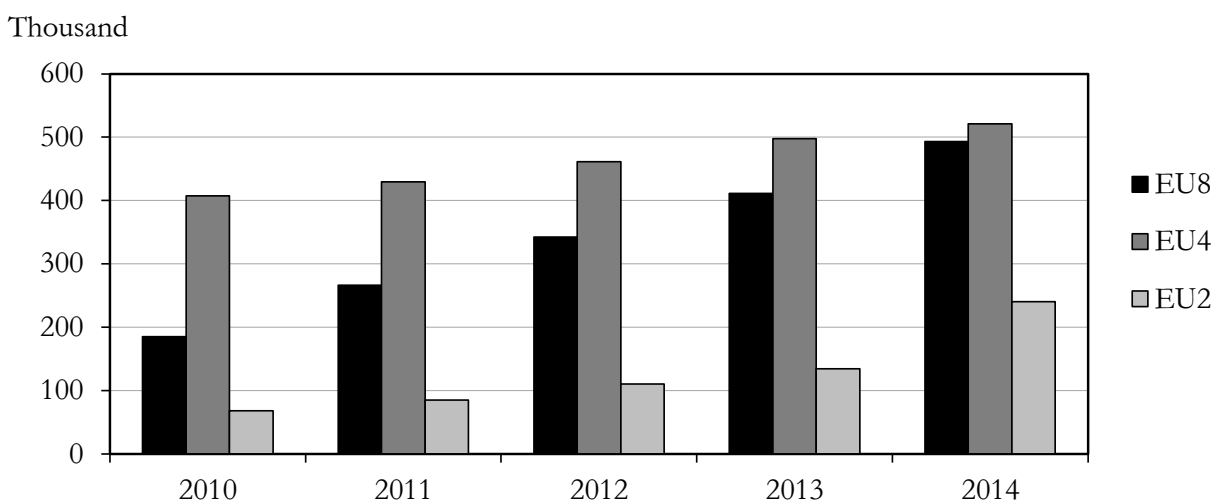

Source: Data of the Federal Ministry of the Interior and the Federal Office for Migration and Refugees (Germany).

The internationalisation of tertiary education has led to increasing mobility of students. Germany is one of the most important destination countries for international students worldwide, ranked five on the global scale (after the United States, the United Kingdom, Australia and France) (DAAD-DZHW 2017, p. 22.). In the period of 2000-2016, the number of international students ${ }^{11}$ in Germany more than doubled from 112,883 to 251,542 (see Figure 4).

Figure 4

\section{International students in Germany}

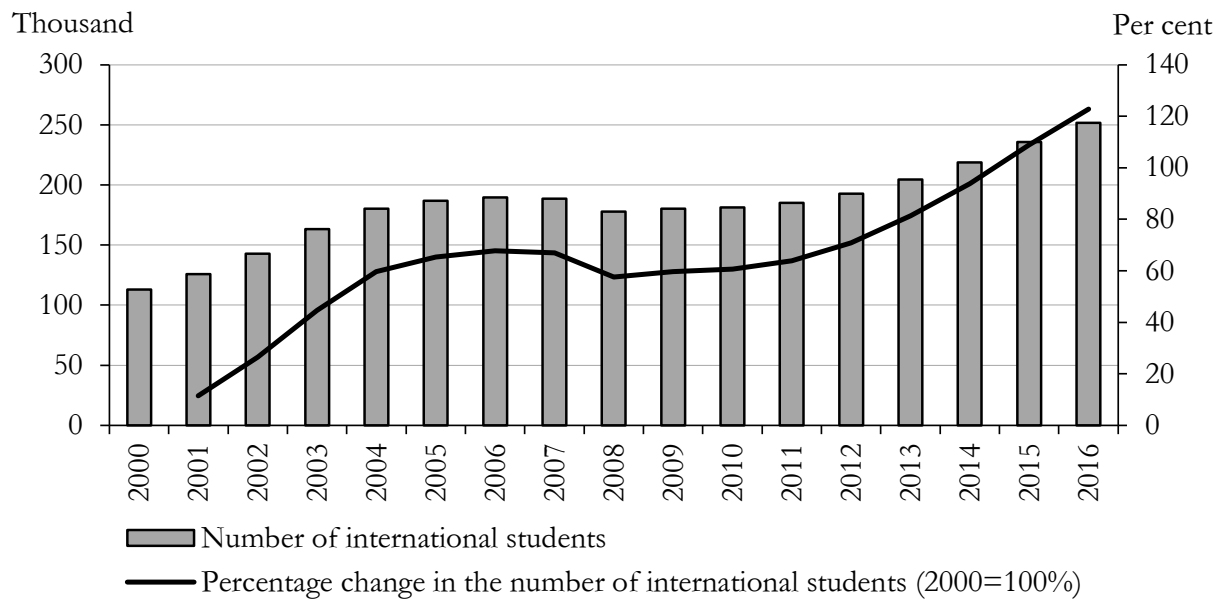

Source: DAAD-DZHW (2017).

11 Those students who obtained their university entrance certificate abroad (DAAD-DZHW 2017).

Regional Statistics, Vol. 8. No. 1. 2018: 3-28; DOI: 10.15196/RS080101 
Among the 'quantitatively' most important source countries, China and the Russian Federation have held top positions for years, while India has been the fastest growing source country over the last few years with an increase from 3,821 in $2009 / 2010$ to 13,537 in 2015/2016. EU countries have always been among the top ten countries and thus contribute considerably to the internationalisation of German universities (see Table 1).

Table 1

Main source countries of the educational migration to Germany

\begin{tabular}{|c|c|c|c|c|}
\hline \multirow[b]{2}{*}{ Position } & \multicolumn{2}{|c|}{ Winter term 2009/2010 } & \multicolumn{2}{|c|}{ Winter term 2015/2016 } \\
\hline & Country & $\begin{array}{l}\text { Number } \\
\text { of students }\end{array}$ & Country & $\begin{array}{c}\text { Number } \\
\text { of students }\end{array}$ \\
\hline 1 & China & 22,779 & China & 32,268 \\
\hline 2 & Russian Federation & 9,764 & India & 13,537 \\
\hline 3 & Poland & 8,467 & Russian Federation & 11,413 \\
\hline 4 & Bulgaria & 8,266 & Austria & 10,129 \\
\hline 5 & Turkey & 6,635 & Italy & 8,047 \\
\hline 6 & Ukraine & 6,326 & France & 7,330 \\
\hline 7 & Austria & 6,209 & Cameroon & 7,106 \\
\hline 8 & Morocco & 5,533 & Ukraine & 6,941 \\
\hline 9 & Cameroon & 5,383 & Turkey & 6,930 \\
\hline 10 & France & 5,324 & Bulgaria & 6,840 \\
\hline
\end{tabular}

In the context of a demographically shrinking labour force, there is a growing interest to hold back international students after graduation and motivate them to stay long term. Since the implementation of the new migration law in 2005, regulations have been liberalised considerably, with the possibility to obtain a residence permit for a job search for a period of 12 months after graduation (expanded further to 18 months in 2012). During the initial years after the implementation of this new regulation, this possibility was rarely exploited. In 2006 only 1,954 persons held the residence permit for job search after graduation, while 14,860 third country nationals graduated from a German university in the same year (BMI 2007, p. 63.). Until the year 2015, the number of permits for job search after graduation increased to 7,569 , while 32,515 third country nationals graduated in the same year (BMI 2016, p. 79.). However, these numbers do not provide any further information about the biography of the permit holder, and completely leave out information on the mobility behaviour of EU citizens among international students.

Several surveys analysed the stay intentions and mobility behaviour of international students and examined relevant factors that shape those decisions (HanganuHeß 2014; Heß 2009; Mayer et al. 2012; FSVR 2011, 2012, 2015, 2017). They all

Regional Statistics, Vol. 8. No. 1. 2018: 3-28; DOI: 10.15196/RS080101 
revealed a high probability of stay after graduation. In 2011, an online-survey among third country students showed that 80 per cent of the master's students and 67 per cent of the $\mathrm{PhD}$ students thought about staying on in Germany after graduation; however, this was for a shorter time span of up to five years (FSVR 2012, p. 38.). Almost half of the survey participants expected good opportunities to find an adequate job in Germany. Compared to all survey participants, the 'stayers' were relatively younger, and were already staying in Germany for a comparatively long time, had studied master's programmes rather than $\mathrm{PhD}$ programmes and frequently studied the so-called MINT-sciences. ${ }^{12}$ The most recent survey conducted was a longitudinal survey which approached international students during and after completion of their studies. The results showed that 70 per cent of the participants planned to stay on in Germany after graduation. Among those, 81.8 per cent still resided in Germany at the time of the second survey, while of those who said they did not plan to stay, 40.2 per cent continued to reside in the country. More than one-third of the survey participants was working at the time of the second survey, while another third was still looking for a job (FSVR 2017).

\section{Migratory changes in the course of the European financial crisis}

The European economic and financial crisis has heavily influenced the inner European mobility schemes since 2008. On the one hand, the economic downturn in destination countries caused EU free movers to leave those countries and either return home or look for alternative migratory goals. This is, for example, the case of Ireland which had negative migration balances since 2009 owing to the departure of EU8 citizens who preferred moving to Ireland, the United Kingdom and Sweden since 2004, as those three countries had already opened up their labour markets. On the other hand, countries that formerly were destination countries for labour migration became countries of departure. This was the case of the Mediterranean EU countries that - most notably in the case of Spain ${ }^{13}$ - turned from immigration to emigration countries, with a significant share of emigrants heading to Germany (Domínguez-Mujica-Pérez García 2017, p. 28.). Consequently, and after years of very moderate mobility between Southern Europe and Germany with around 40,000 arrivals per year, migration numbers started climbing in 2008 and quickly reached a level of more than 100,000 arrivals in 2012. Since 2013, more than 150,000 arrivals of persons with Greek, Italian, Portuguese, and Spanish citizenship were recorded per year. As the number of departures from Germany only increased slightly, those countries - after years of producing negative balances - produced net migration gains since 2010, with a peak in 2013 of plus 64,794. Regarding the num-

12 Mathematics, information sciences, natural sciences, technical sciences.

${ }^{13}$ Spain, after years of net immigration, turned to net emigration in 2010. The negative migration balance quickly increased and reached its peak in 2013, when the emigration numbers almost doubled the immigration numbers and led to a net emigration of 251,531 persons (BMI 2016, p. 241.).

Regional Statistics, Vol. 8. No. 1. 2018: 3-28; DOI: 10.15196/RS080101 
bers by country, we observe significant differences in the size and development of arrival numbers (see Figure 5). While Italy during the observation period of 2005-2015 always provided the largest number of migrants (maximum: 74,105 in 2015) and the longest continuous period of increase, the number of Greek immigrants rapidly increased from around 8,000 in the years before 2010, to more than 30,000 since $2012 .{ }^{14}$ This is most remarkable if we compare the countries' population numbers which are 11.2 million for Greece compared to 60.5 million for Italy.

Figure 5

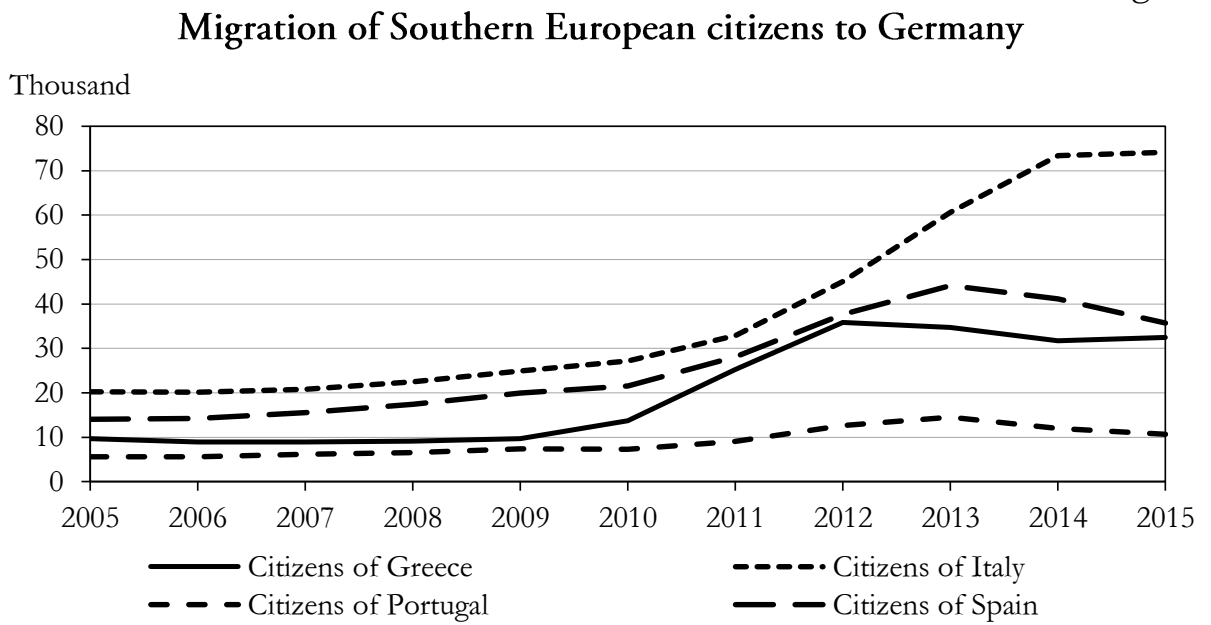

Source: BMI (2016).

The term 'crisis migration' refers to the main push-factor of the recent movements, notably the effects of the global economic and financial crisis which especially hit the core branches of Southern European countries and caused high unemployment rates, especially among young adults and university graduates who were searching for their first employment opportunity (Hernández Peinado-Montero González 2013). The effects of the economic downturn were felt more acutely in these countries, as prior transformations in the demographic, societal and educational landscape did not result in necessary economic or labour market reforms (Glorius 2015, Glorius-Domínguez-Mujica 2017). However, obviously the described mobility behaviour was not only a result of economic rationality and structural criteria such as freedom of movement, but was also fuelled by soft factors such as existing social networks between Southern European migrants and individuals in Germany, who helped facilitate the move by providing information and practical and emotional support. Those social networks developed prior mobility processes

14 This reflects the general migratory dynamics from Greece, where departures more than doubled between 2009 (60,363 departures) and the peak year 2012 (124,694 departures) (BMI 2016, p. 241.).

Regional Statistics, Vol. 8. No. 1. 2018: 3-28; DOI: 10.15196/RS080101 
such as the guest-worker movement of the 1960s and 1970s, and owing to student mobility, tourism, short-term internships or jobs abroad.

With reference to the research literature that examined the motivations, expectations and experiences of the Southern European 'crisis' migrants, we cannot draw a consistent picture, as there seem to be winners and losers of the migration process (Glorius-Domínguez-Mujica 2017, Lafleur-Stanek 2017). Most studies stressed the significant language barriers which aggravated the labour market and hampered the social integration of Southern European migrants in Germany, causing the return of many of those who arrived around 2009. In addition, the emotional bonds to the home country were a strong incentive to return after some years of working abroad. Similar to the example of student migration, the societal and structural conditions in the EU support multiple mobilities and translocal livelihoods, and therefore, a macroeconomic balance of the long-term effects of labour migration for a given country is difficult.

\section{Public discourses on migration}

The discourses that developed around the crisis migration from Southern Europe to Germany show very well the connectivity between old stereotypes, the structural embeddedness of a discourse and the selectivity of arguments. Owing to geographical similarities, the Southern European crisis migration to Germany was first labelled 'new guest-worker migration' (Glorius 2015, Göler-Köppen 2015), but it soon turned out that not only the arriving migrants, but also the institutional regulations and the public discourses differed significantly from the guest-worker recruitment in the 1960s and 1970s. While the guest-worker recruitment was a highly regulated mass migration focusing on a low-skilled labour force, the more recent migrations from Southern Europe were channelled by individual labour market actors such as small and medium sized companies, or chambers of commerce which owing to labour force shortages - undertook significant efforts to implement recruitment initiatives in Southern Europe (Godenau 2017, Meinardus 2017). They were not only assisted by state programmes that supported the mobility of candidates, ${ }^{15}$ but also by public discourses by high-ranking state representatives (such as German Chancellor Angela Merkel, who publicly encouraged Spanish engineers to move to Germany, stressing the positive labour market situation there).

A comparative analysis of media discourses on migration from different European source regions revealed major differences and stereotypes, especially regarding migrants' labour market integration or dependence on social transfer payment.

\footnotetext{
${ }^{15}$ For example, the Program for supporting labour migration of trainees and unemployed workers from Europe' (MobiPro-EU) was put into practice in January 2013. It provided financial support for language training and travel costs for migratory moves, internships, or job interviews in Germany, which attempted to reduce mobility obstacles that usually hindered the intra-European mobility of young adults. The programme had a financial frame of 140 million EUR and was designed to run until 2016 (http://www.bmas.de/DE/Themen/Arbeitsmarkt/ Modellprogramme/mobi-pro-eu.html).
}

Regional Statistics, Vol. 8. No. 1. 2018: 3-28; DOI: 10.15196/RS080101 
The media analysis was based on a selection of media articles that were published in the liberal weekly magazine 'Die Zeit' between 2003 and 2014, thus covering the two EU expansions and the onset of the financial crisis which resulted in increasing migration numbers. The selection of media articles was done using the search term 'migration' and the terms 'Poland', 'Romania' and 'Spain', representing the three groups of migration source countries that were discussed in the earlier chapters. The search revealed 97 relevant articles, 22 focusing on Poland, 12 on Spain and 63 on Romania. A comparison of the main arguments used in the articles revealed major differences in the connotation of migration with regards to the three selected countries.

Media articles on Spanish immigration to Germany were firmly linked to the economic and financial crisis as a trigger for increasing migration numbers, and the high percentage of academics among the immigrants was highlighted. One article portrayed the integration path of a young Spanish engineer in Germany and traced not only the individual efforts of integration, but also the high satisfaction of the migrant. The entire article was characterised by a high appreciation of the migrant, as well as the positive impression left by Germany as a host country. Another case report showed the situation of the employer, stressing the high demand for skilled workers, which created the necessity for recruitment strategies abroad. The contributions showed strong discursive entanglements with demographic change in Germany and the resulting shortage of skilled workers. The main concern with respect to the Spanish immigration was that the young, well-educated migrants will not stay permanently in Germany.

Moreover, the media articles on Polish migration depicted a positive picture of the recent migration and gave factual information on migration numbers, stressing the fact that Poland is quantitatively the most important source country for EU internal migration to Germany. The articles presented survey data on the attitude of the Polish population towards the EU, Germany and Germans, or portrayals of Polish migrants in Germany and their integration experiences. Complementary reports on the increasing shortage of skilled labour in Poland in the context of emigration allowed readers to find common ground between the two countries. Freedom of movement was presented as a gain for Germany's labour market, if not as an absolute necessity. In doing so, the media discourse withdrew from earlier fears of a mass migration from Poland and rather raised concerns that the migration will not be enough to fill the demographic gaps.

The media coverage of Romania was completely dominated by debates on the exploitation of German social systems, for which the term 'poverty immigration' was coined. At the turn of 2013/2014 and on the eve of full freedom of movement for Romania and Bulgaria, the number of articles on this topic greatly increased. These articles depicted a strong dominance of political actors, and above all the conservative party Christian Socialist Union (CSU) published a strategy paper on Romanian migration at the beginning of 2014 with the telling title 'If you cheat, you'll be

Regional Statistics, Vol. 8. No. 1. 2018: 3-28; DOI: 10.15196/RS080101 
kicked out!'16 This paper and the accompanying reports reflected the migration discourse in relation to the EU2 countries. The articles published in 2014 reported on the attitude of the parties towards poverty immigration and commented on immigration numbers and the share of migrants receiving social benefits in Germany. There were reports from the major urban destinations of Romanian and Bulgarian migrants in Germany as well as reports that used data and expert statements to contrast the stigmatisation of immigrants from Romania and Bulgaria. All these had in common the use of the term 'poverty immigration' without comment, meaning that this term has already penetrated the public debate so strongly that it has become part of public knowledge and no longer needed explanation. This was contrasted by a very small number of articles that critically reflected the consequences of the poverty debate for the image of Germany as an immigration country, primarily arguing on economic grounds ('economy is annoyed by immigration debate').

The media analysis revealed that there are several stereotypes on migration and migrants in the public discourse, which reflects a hierarchy of immigrants in terms of integration success and economic utility. This hierarchy is deeply connected to old and new stereotypes of the relevant groups and their home countries, and it is also reflected by the migrants, and thus can create incentives to return or move on owing to anticipated xenophobia or discrimination.

\section{The 'refugee crisis' of 2015 and its consequences}

Reflecting on recent migration processes to Germany, the arrival of asylum seekers in rapidly growing numbers since 2014 is the most impressive, drastic and consequential migratory movement since the end of the Second World War. It not only changed the ethnic, cultural and religious fabric of places and spaces of arrival, but also triggered an increasingly polemic discussion on security, identity and belonging within German society, which was also reflected by the election results of the parliamentary elections of 24 September 2017.

\section{Dynamics of refugee migration to Germany}

A long-term perspective on the reception of asylum seekers in Germany shows that as early as the beginning of the 1990s there were an exceptionally large number of asylum applications. Many of those were filed by refugees from the Balkan wars and displaced persons from the disintegrating Yugoslav state. This led to severe restriction of the national law of asylum in 1992, which - among other measures introduced the concept of safe third states and later became part of the EU Dublin regulation. Following these regulatory changes, asylum application numbers dropped rapidly and stayed at low levels of around 20,000 until the early 2000s (see Figure 6). Owing to political conflicts in the Near East and the constant inflow

${ }^{16}$ Original 'Wer betrügt, der fliegt', strategy paper of the CSU meeting held on 7 January 2014.

Regional Statistics, Vol. 8. No. 1. 2018: 3-28; DOI: 10.15196/RS080101 
of refugees via the Mediterranean in the 2000s, countries of arrival such as Italy were facing severe reception and accommodation problems, and refugees started to move onwards, for example, to Germany. Since 2014, refugees from the West Balkans and those travelling over the Balkan route have led to rapidly increasing arrival numbers of asylum seekers in Germany, culminating in a maximum of 890,000 registered entries and 441,899 asylum applications in 2015 (BMI 2016). As the Federal Office for Migration and Refugees fell behind in the registration and application procedures, the number of asylum applications continued to increase in 2016 (around 722,000 first time applications), even though the number of arriving asylum seekers dropped since the closure of the Balkan route in March 2016 (BMI 2016).

Figure 6

\section{Development of the number of asylum applications in Germany}

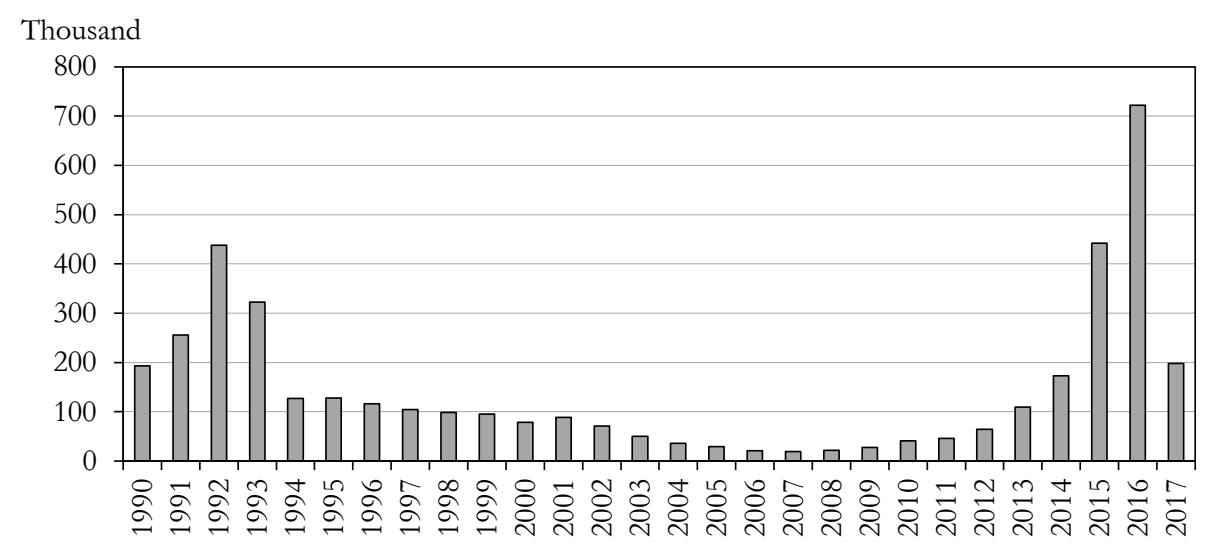

Source: Data of the Federal Office for Migration and Refugees (Germany).

In 2015, the main countries of origin were regions in Europe, Asia and the Near East (see Figure 7). The main source country for asylum seekers was Syria with more than one-third of all asylum applications, followed by Albania $(12.2 \%)$ and Kosovo (7.6\%). Asylum seekers from Afghanistan ranked four (7.1\%), followed by asylum seekers from Iraq (6.7\%) and Serbia (3.8\%). Around 12,000 asylum seekers were stateless, who were mainly Palestinians from Syria. Eritreans ranked eighth in the asylum application statistics (BAMF 2016b, p. 15.). After the proclamation of Albania, Kosovo and Montenegro as safe countries of origin in October 2015, the introduction of border controls along the Balkan route and the March 2016 cooperation agreement with Turkey aiming to sustain irregular migration from Turkey into the EU, resulted in a decline in arrival numbers of asylum seekers and significant changes in the composition of flows. In 2016, the main groups of asylum seekers came from Syria (17.5\%), Afghanistan (9.6\%), Iraq (8.6\%), Eritrea (8.6\%) and Iran (4.1\%) (BAMF 2016a).

Regional Statistics, Vol. 8. No. 1. 2018: 3-28; DOI: 10.15196/RS080101 
Number of asylum applications by country, 2015

Figure 7

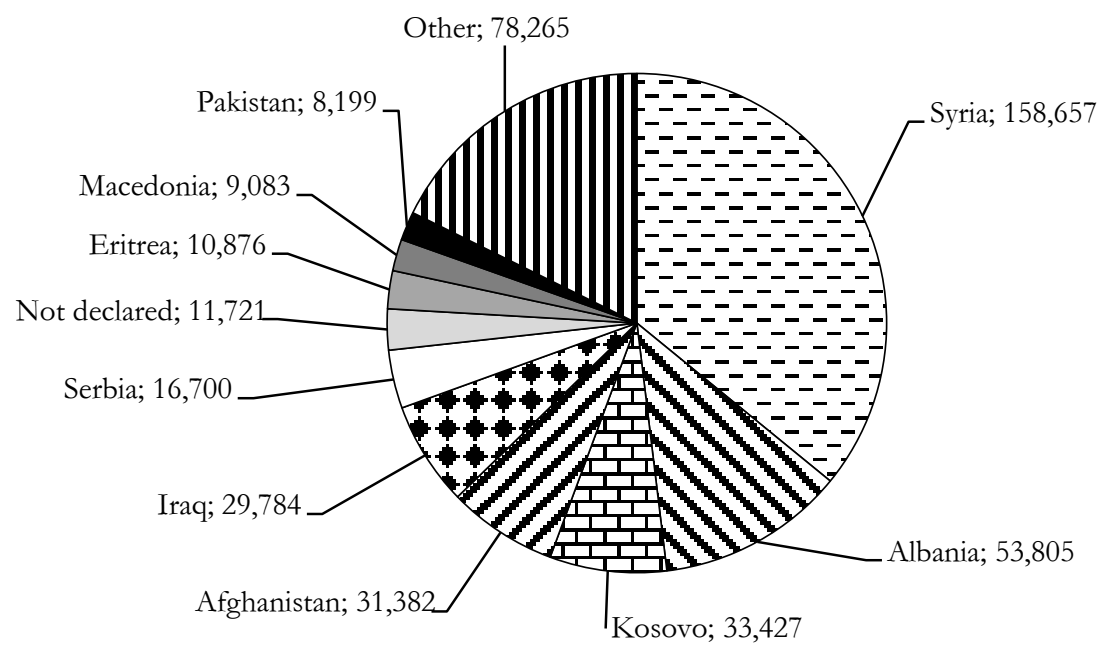

Source: Data of the Federal Office for Migration and Refugees (Germany).

However, the influx to Europe remains constantly high, as shown by the rising numbers of those travelling over the Central Mediterranean route and by reports and assessments from Turkey and the North African coasts. Regardless of the development of national and European refugee politics, it can be assumed that the humanitarian obligation to take in asylum seekers in Germany will lead to the inclusion of further asylum seekers in considerable numbers in the medium and long term.

\section{The asylum procedure in Germany}

The asylum procedure starts after crossing the border and claiming asylum with an official authority. This is followed by registration in the so-called EASY system (databank for the initial distribution of asylum seekers), where personal data, a photograph and fingerprints are stored. Asylum seekers receive a registration certificate that is sent to a first reception facility of one of the 17 German federal states. In order to derive a fair distribution, a quota is defined for each federal state, based on the amount of tax revenues and population size. In 2015, North Rhine-Westphalia had the highest quota $(21.2 \%)$, while the federal state of Bremen took in the lowest quota of asylum seekers (0.9\%) (BAMF 2016b, p. 13.).

Asylum seekers are obliged to stay between six and a maximum of twelve weeks in the federal first reception facility so that they are made available at any time during the initiation of the asylum procedure. The reforms of the asylum law of 2016 introduced further restrictions for asylum seekers from safe countries of origin, who are now obliged to stay in the first reception facility for the entire duration of the

Regional Statistics, Vol. 8. No. 1. 2018: 3-28; DOI: 10.15196/RS080101 
asylum procedure. Furthermore, an accelerated procedure was introduced by which an asylum decision should be made within a week (Bundesregierung 2016). By contrast, the average duration of the asylum decision process in the autumn of 2015 was five months, varying over a wide range and depending on the country of origin. Moreover, some asylum seekers had to wait for several months until the Federal Office for Migration and Refugees had the capacity to register their asylum application (Zeit online 10.10.2015). This explains the 63\% increase in asylum applications from 2015 to 2016 compared to 2015 (see Figure 6), while the arrival numbers declined in the same period from 890,000 to 280,000 (by 68\%).

The asylum claims are decided by the Federal Office for Migration and Refugees based on German Constitutional Law, Asylum Law and the Geneva Convention. There are three different statuses of protection: 1. refugee status (based on Art. 16 Constitutional Law or $\$ 3,1$ Asylum Procedure Act), 2. subsidiary protection $(\$ 4,1$ Asylum Law) and 3. toleration owing to obstacles towards deportation ( $\$ 60$, $5 / 7$ Residence Act). Owing to the high proportion of refugees from war and crisis areas since 2015, almost half of the asylum decisions of 2015 and 2016 granted refugee status or subsidiary protection (see Table 2).

Table 2

\begin{tabular}{c|c|c|c|c|c|c}
\multicolumn{6}{c}{ Number of first instance decisions on asylum applications by outcome } \\
\hline \multirow{2}{*}{ Year } & Total & $\begin{array}{c}\text { Refugee status } \\
\text { (Article 16 } \\
\text { Constitutional } \\
\text { Law or \$3, 1 } \\
\text { Asylum } \\
\text { Procedure Act) }\end{array}$ & $\begin{array}{c}\text { Subsidiary } \\
\text { protection } \\
(\$ 4,1 \text { Asylum } \\
\text { Law) }\end{array}$ & $\begin{array}{c}\text { Toleration } \\
\text { owing } \\
\text { to deportation } \\
\text { obstacles (\$60, } \\
\text { 5/7 Residence } \\
\text { Act) }\end{array}$ & $\begin{array}{c}\text { Negative } \\
\text { decision }\end{array}$ & $\begin{array}{c}\text { Formal } \\
\text { decision* }\end{array}$ \\
\hline 2013 & 80,978 & 10,915 & 7,005 & 2,208 & 31,145 & \\
2014 & 128,911 & 33,310 & 5,174 & 2,079 & 43,018 & 45,330 \\
2015 & 282,726 & 137,136 & 1,707 & 2,072 & 91,514 & 50,297 \\
2016 & 695,733 & 256,136 & 153,700 & 24,084 & 173,846 & 87,967 \\
2017 & 603,428 & 123,909 & 98,074 & 39,659 & 232,307 & 109,479
\end{tabular}

* Decisions based on Dublin regulation; withdrawal of application.

Source: BAMF (2017).

Persons who are granted refugee status receive a residence permit for a period of at least three years and gain unlimited access to the labour market. Under certain conditions, the residence permit can later be converted into a settlement permit. Persons who are granted subsidiary protection or a temporary toleration status are eligible for a one-year residence permit. This can be repeatedly extended if the reasons for protection, or obstacles to deportation, remain. After a five-year stay, a settlement permit can be obtained. Those applicants whose asylum application is rejected receive an order to leave the country. Under certain conditions, financial

Regional Statistics, Vol. 8. No. 1. 2018: 3-28; DOI: 10.15196/RS080101 
measures to support the return are granted (BMI 2016). In 2016, 54,069 persons left Germany on the basis of federal return aid programmes, and 25,375 were deported. In June 2017, the central register of foreigners consisted of 226,457 persons who were obliged to leave the country, of which 159,678 persons had toleration status owing to deportation obstacles (Deutscher Bundestag 2017).

\section{Regional distribution of asylum seekers}

Within the federal states, the distribution of asylum seekers is carried out on the basis of a distribution key which mainly respects the population structure of the counties and the municipalities' ability to accommodate asylum seekers (AumüllerDaphi-Biesenkamp 2015, p. 22., IW Köln 2016, p. 27.). The local arrangement of the accommodation is regulated by corresponding country laws and ordinances which contain considerable differences, for example, with regard to institutional responsibilities and administrative arrangements for initial and long-term accommodation (Müller 2013, p. 15). Generally, the main focus of the asylum management and legal regulations during the application and decision process is on the accommodation management, while only some federal laws foresee binding agreements with regard to integration measures or psychosocial care of asylum seekers (Aumüller-Daphi-Biesenkamp 2015, p. 22.). Furthermore, at the local level, civil society organisations and volunteers play a major role in all aspects of integration of asylum seekers.

During the asylum procedure, asylum seekers are obliged to reside at their assigned places of residence and are subject to restrictions of movement which mostly refer to the territory of the federal state they were assigned to, but sometimes is narrowed down to the county of residence. The new Integration Act of 31 July 2016 introduced a three-year residence obligation for recognised refugees who are not able to secure their livelihood by their own means ( $\$ 2$ Integration Act, $\$ 12 \mathrm{a}$ Residence Act). Since its implementation, it has been a highly contested measure, as opponents argue that residence obligations prohibit social integration and, furthermore, do not comply with EU law (El-Kayed-Hamann 2016).

The increasing numbers of asylum seekers during 2015 challenged the longstanding practice of housing and care for asylum seekers, notably the effort of many municipalities to provide for decentralised housing and sound integration programmes for asylum seekers. Instead, the focus turned to larger housing units and emergency shelters, for example in gyms, abandoned public buildings or warehouses, or container buildings and tent camps. For many municipalities, it has become increasingly difficult to arrive at a socially balanced distribution of asylum seekers across the community, especially while taking into account the needs of the local population for low-cost housing. In some places, discourses on fair distribution of asylum seekers and the availability of social housing have turned into a generalised debate on social justice, and local authorities have to respond to the emer-

Regional Statistics, Vol. 8. No. 1. 2018: 3-28; DOI: 10.15196/RS080101 
gence of social envy (Glorius 2017). Especially in rural areas of Eastern Germany, the mixture of social envy and lack of intercultural competence seems to lead to a hostile attitude towards asylum seekers, which not only prevents integration, but also triggers verbal and physical assaults (Glorius-Schondelmayer 2018).

Evaluating the current practice of regional distribution, many stakeholders are questioning the idea of 'burden sharing' on the basis of mere population share and tax revenues. Especially regarding rural regions, the existing infrastructure is often perceived as not being adequate for the reception, accommodation and integration of asylum seekers. Rural areas usually have low levels of diversity and lack important ethnic infrastructure such as food shops or mosques, as well as infrastructure that would be necessary for integration (language teachers, qualification courses or psychotherapeutic offers with multilingual and interculturally trained staff). On the other hand, especially urban agglomerations fear a significant inward mobility of accepted refugees from rural municipalities they were assigned to during the asylum application procedure, owing to better opportunities for labour market access and ethnic networks. In 2017 and 2018, several county capitals, after having experienced relocation of persons with refugee status from the county peripheries to the county capital, claimed that their infrastructure could not integrate more refugees. Thus, as a specific measure of the residence obligation, residence bans ( $\$ 12 \mathrm{a}$ Abs. 4 Residence Act) were introduced in four German cities until January 2018.

\section{Summary and outlook}

An overview of the main migration processes and discourses in Germany have revealed that Germany has a long-standing history of migratory connections, mainly to other European states. Especially in the context of an ageing and declining society, qualified labour migration is seen as a necessity for further economic prosperity and the maintenance of Germany's innovative potential. However, on the one hand, as the elaboration above has shown, the demand and supply side of migration can vary considerably, owing to the complexity of migration motives and individual migration decisions. On the other hand, the multidimensionality of external causes for migration and political regulations aiming to steer migration, sometimes with unintended consequences, is observed. Looking back, the termination of guestworker recruitment aiming to reduce the number of migrants in Germany brought about the opposite result, as many of the present guest workers, anticipating that temporary migration schemes were ending, permanently settled in Germany and brought in their relatives via family unification. During the EU expansion of 2004, restrictions for migrants from Central and Eastern Europe somehow collided with the effort to increase high-skilled migration to Germany, and ended with an increase in low-qualified labour migration. Finally, as the most recent refugee migration showed, the abolition of labour migration schemes that used to be in operation between Southern Europe and the Maghreb countries until the 1990s or between

Regional Statistics, Vol. 8. No. 1. 2018: 3-28; DOI: 10.15196/RS080101 
Germany and Yugoslavia until the 1970s prevents the possibility of alleviating the economic pressure in these countries which in particular suffer from high levels of youth unemployment (Little-Vaughan-Williams 2017). Consequently, many migrants from those countries joined the flow of war victims from the Near East and attempted to enter the European Union via the 'asylum entrance'.

Finally, as shown above, public discourses developing around the migration topic are also highly selective, often stereotypical, and tend to mingle various topics that are currently at stake in order to arrive at simplified solutions. This is the case in the recent debate on refugee migration in Europe, which relates to debates on culture, identity, security, criminality and religion and is increasingly instrumentalised by right wing parties, who collected a considerable share of votes during the last parliamentary elections throughout Europe. Reflecting on those recent developments of public opinion, we must not forget that migration has always been a highly sensitive topic for public debates, as it contests the imagination of national unity based on common values, habits, and on a relatively ethnic homogeneity within the European nation states. The European unification process, having started as an initiative for peace and having developed into a neoliberal economic project, has left out the question of how European citizens may identify with the European idea and find alternatives to re-nationalisation movements in order to stabilise their identity in turbulent times. Thus, in order to solve actual imbalances in the European migration and asylum system, questions of social justice and common European values will also need to be addressed throughout the European countries and at the EU level.

\section{REFERENCES}

APSITE, E. (2010): Geographical aspects of mobility in the new European Union member states: The case of Latvian migrants in the United Kingdom Latvijas Universitates Raksti. Zemes un Vides Zinatnes 752: 295-307.

Aumüller, J.-DAphi, P.-BIESEnKamp, C. (2015): Die Aufnahme von Flüchtlingen in den Bundesländern und Kommunen Behördliche Praxis und zivilgesellschaftliches Engagement Expertise gefördert und herausgegeben von der Robert Bosch Stiftung. Stuttgart.

BADE, K. (2002): Europa in Bewegung. Migration vom späten 18. Jahrhundert bis zur Gegenwart C.H. Beck, München.

BALÁŽ, V. -Williams, A. (2004): Been there, done that: International Student Migration and Human Capital Transfers from the UK to Slovakia Population, Space and Place 10 (3): 217-237. https://doi.org/10.1002/psp.316

Balibar, E.-WALlersteIn, I. (1990): Rasse, Klasse, Nation - Ambivalente Identitäten Argument Verlag mit Ariadne, Hamburg.

Bertoli, S.-BrüCKer, H.-FernándeZ-Huertas MoragA, J. (2013): The European Crisis and Migration to Germany: Expectations and the Diversion of Migration Flows IZA Discussion Paper 7170, Bonn.

Regional Statistics, Vol. 8. No. 1. 2018: 3-28; DOI: 10.15196/RS080101 
Bundesagentur fÜr ArBeIt (BA) (2014): Hintergtundinformation. Auswirkungen der Arbeitnehmerfreizügigkeit und der EU-Schuldenkrise auf den deutschen Arbeitsmarkt Nürnberg.

Bundesamt FÜr MigRATION UND FLÜCHTLINGE (BAMF) (2016a): Ablauf des deutschen Asylverfahrens. Ein Überblick über die einzelnen Verfahrensschritte und rechtlichen Grundlagen Nürnberg.

Bundesamt FÜr MigRATION Und FLÜChtLinge (BAMF) (2016b): Aktuelle Zahlen zu Asyl. August 2016 Nürnberg.

Bundesamt FÜr Migration und FlüChtlinge (BAMF) (2016c): Das Bundesamt in Zahlen 2015. Asyl Nürnberg.

BUNDESMINISTERIUM DES INNERN (BMI) (2007): Migrationsbericht des Bundesamtes für Migration und Flüchtlinge im Auftrag der Bundestegierung. Migrationsbericht 2006 Berlin.

BundeSMinisterium DES INNERN (BMI) (2008): Migrationsbericht des Bundesamtes für Migration und Flüchtlinge im Auftrag der Bundesregierung. Migrationsbericht 2007 Druck-Buch-Verlag, Berlin.

BUNDESMINISTERIUM DES INNERN (BMI) (2014): Migrationsbericht des Bundesamtes für Migration und Flüchtlinge im Auftrag der Bundesregierung. Migrationsbericht 2012 Druck-Buch-Verlag, Berlin.

BUNDESMINISTERIUM DES INNERN (BMI) (2016): Migrationsbericht des Bundesamtes für Migration und Flüchtlinge im Auftrag der Bundesregierung. Migrationsbericht 2015 Berlin.

BundesRegierung (2016): Asylpaket II in Kraft. Kürzere Verfahren, weniger Familiennachzug https://www.bundesregierung.de/Content/DE/Artikel/2016/02/ 2016-02-03-asylpaket2.html (downloaded: 15.09.2016).

CURRIE, S. (2007): De-skilled and devalued: The labour market experience of Polish migrants in the UK following EU enlargement International Journal of Comparative Labour Law and Industrial Relations 23 (1): 83-116.

CYRUS, N. (1994): Flexible work for fragmented labour markets. The significance of the new labour market regime in the Federal Republic of Germany Migration 26: 97-124.

Deutscher AKADEMISCHER AUSTAUSCHDIENST (DAAD)-DEUTSCHES ZENTRUM FÜr HOCHSCHUL- UND WiSSENSCHAFTSFORSCHUNG (DZHW) (2017): Wissenschaft Weltoffen 2017. Daten und Fakten zur Internationalität von Studium und Forschung in Deutschland W. Bertelsmann Verlag, Bielefeld.

Deutscher Bundestag (2017): Antwort der Bundesregierung auf die Kleine Anfrage der Abgeordneten Ulla Jelpke, Frank Tempel, Sevim Dağdelen, weiterer Abgeordneter und der Fraktion DIE LINKE. - Drucksache 18/13114 - Abschiebungen und Ausreisen im ersten Halbjahr 2017 Drucksache 18/13218, Berlin.

Domínguez-MujicA, J. (ed.) (2016): Global Change and Human Mobility Springer, Singapore.

Domínguez-Mujica, J.-PÉREZ García, T. (2017): The economic crisis and the Southern European migration model. In: GLORIUS, B.-DomíngueZ-MujICA, J. (eds.) European Mobility in Times of Crisis. The New Context of European South-North Mobility pp. 17-48, transcript, Bielefeld.

Regional Statistics, Vol. 8. No. 1. 2018: 3-28; DOI: 10.15196/RS080101 
DOOMERNIK, J.-KOSLOWSKI, R.-THRÄNHARDT, D. (2009): The battle for the brains: Why immigrant policy is not enough to attract the highly skilled The German Marshall Fund of the United States, Washington, D.C.

Drinkwater, S.-EAde, J.-GARAPICH, M. (2009): Poles apart? EU enlargement and the labourmarket outcomes of immigrants in the United Kingdom International Migration 47 (1): 161-190. https://doi.org/10.1111/j.1468-2435.2008.00500.x

DüVELL, F. (2004): Highly skilled, self-employed and illegal immigrants from Poland in the United Kingdom, Working Papers. Centre for Migration Studies, Warsaw.

EL KAYED, N.-HAMANN, U. (2016): WOHNSITZAUfLAGE FÖRDERT NICHT DIE INTEGRATION. Mediendienst Integration https://mediendienst-integration.de/artikel/ kritik-wohnsitzauflage-und-zuzugssperre-fuer-fluechtlinge-am-beispiel-vontuerken-und-spaetaussiedle.html (downloaded: 12.02.2018)

ELSNER, E.-M.-ElSNER, L. (1994): Zwischen Nationalismus und Internationalismus. Über Ausländer und Ausländerpolitik in der DDR 1949-1990 Rostock.

ENTZINGER, H. (1998): Zu einem Modell der Inkorporation von einwanderern: das Beispiel der Niederlande. In: Bommes, M. -Halfmann, J. (eds.) Migration in nationalen Wohlfahrtsstaaten pp. 105-122, Osnabrück.

European Commission/European Migration Network (2016): Country Factsheet: Germany 2016 https://ec.europa.eu/home-affairs/sites/homeaffairs/files/11a_ germany_country_factsheet_2016_en_0.pdf (downloaded: 14.09.2016)

FORSCHUNGSBEREICH BEIM SACHVERSTÄNDIGENRAT DEUTSCHER STIFTUNGEN FÜR INTEGRATION UND MigRATION (FSVR) (2011): Vom internationalen Studierenden zum hoch qualifizierten Zuwanderer Berlin.

FORSCHUNGSBEREICH BEIM SACHVERSTÄNDIGENRAT DEUTSCHER STIFTUNGEN FÜR INTEGRATION Und MigRATION (FSVR) (2012): Mobile Talente? Ein Vergleich der Bleibeabsichten internationaler Studierender in fünf Staaten der Europäischen Union Berlin.

FORSCHUNGSBEREICH BEIM SACHVERSTÄNDIGENRAT DEUTSCHER STIFTUNGEN FÜR INTEGRATION UND MigRATION (FSVR) (2015): Zugangstor Hochschule. Internationale Studierende als Fachkräfte von morgen gewinnen Berlin.

FORSCHUNGSBEREICH BEIM SACHVERSTÄNDIGENRAT DEUTSCHER STIFTUNGEN FÜR INTEGRATION UND MigRATION (FSVR) (2017): Vom Hörsaal in den Betrieb? Internationale Studierende beim Berufseinstieg in Deutschland. Eine Studie des SVRForschungsbereichs Berlin.

Glorius, B.-GrabowskA-LusinskA, I.-KuviK, A. (eds.) (2013): Mobility in Transition. Migration Patterns after EU Enlargement IMISCOE Research. Amsterdam University Press, Amsterdam.

GLORIUS, B. (2015): Weder Gäste noch Arbeiter - die neue Zuwanderung aus Spanien nach Deutschland aus einer historisch vergleichenden Perspektive Berichte. Geographie und Landeskunde 98 (1): 5-11.

GLORIUS, B. (2017): The challenge of diversity through migration: refugee reception in the German federal state of Saxony Hungarian Geographical Bulletin 66 (2): 113128. http://dx.doi.org/10.15201/hungeobull.66.2.2

Glorius, B.-Domínguez-MujICA, J. (eds.) (2017): European Mobility in Times of Crisis. The New Context of European South-North Mobility transcript, Bielefeld.

Regional Statistics, Vol. 8. No. 1. 2018: 3-28; DOI: 10.15196/RS080101 
Glorius, B.-SchOndelmayer, A.-C. (2018): Perspektiven auf Fluchtmigration in Ost und West. Ein vergleichender Blick auf kommunale Integrationspraxis Zeitschrift für Vergleichende Politikwissenschaften 12:75-92. https://doi.org/10.1007/s12286017-0368-3

GODENAU, D. (2017): The role of intermediaries in Spanish emigration: past and present. In: Glorius, B.-Domínguez-MujiCA, J. (eds.) European Mobility in Times of Crisis. The New Context of European South-North Mobility pp. 191-214, transcript, Bielefeld.

GÖLER, D.-KÖPPEN, B. (2015): Gastarbeiter reloaded? Anmerkungen zur EUBinnenwanderung in der Schuldenkrise. Ein Editorial Berichte. Geographie und Landeskunde 98 (1): 5-11.

GrabowskA, I.-EngBersen. G. (2016): Social Remittances and the Impact of Temporary Migration on an EU Sending Country: The Case of Poland Central and Eastern European Migration Review 5 (2): 99-117. https://doi.org/10.17467/ceemr.2016.05

GrabowsKA, I.-GARAPICH, M.-JAZWINSKA, E.-RADZIWINOWICZÓWNA， A. (2017): Migrants as Agents of Change. Social Remittances in an Enlarged European Union Palgrave Macmillan, London.

Hammar, T. (ed.) (1984): European Immigration Policy Cambridge University Press, Cambridge. https://doi.org/10.1017/CBO9780511898143

HANGANU, E.-HEß, B. (2014): Beschäftigung ausländischer Absolventen deutscher Hochschulen - Ergebnisse der BAMF-Absolventenstudie 2013 Bundesamt für Migration und Flüchtlinge, Nürnberg.

Heckmann, F. (1981): Die Bundesrepublik: Ein Einwanderungsland? Klett-Cotta, Stuttgart.

Hernández Peinado, M.-Montero González, B. (2013): Un efoque regional de la relación de los jóvenes con el Mercado de Trabajo In: CAmaCHO BALLESTA, J. A.-Jimenéz Olivencia, Y. (eds.) Desarrollo Regional Sostenible en tiempos de crisis pp. 671-690, Universidad de Granada, Granada.

HEß, B. (2009): Bleiben hochqualifizierte Zuwanderer in Deutschland? Befragungsergebnisse des Bundesamtes für Migration und Flüchtlinge Sozialwissenschaftlicher Fachinformationsdienst 2: 11-30.

Hofer, K. (1992): Der Arbeitsstrich. Unter polnischen Schwarzarbeitern. Vienna.

INSTITUT DER DEUTSCHEN WIRTSCHAFT KÖLN (IW KÖLN) (2016): Flüchtlinge regional besser verteilen. Ausgangslage und Ansatzpunkte für einen neuen Verteilungsmechanismus Gutachten für die Robert Bosch Stiftung. Cologne.

IREK, M. (1998): Der Schmugglerzug: Warschau-Berlin-Warschau; Materialien einer Feldforschung. Berlin.

JASPER, D. (1991): Ausländerbeschäftigung in der DDR In: KRÜGER-POTRATZ, M. (ed.) Anderssein gab es nicht: Ausländer und Minderheiten in der DDR pp. 151-189, Waxmann, Münster.

KIEL, S. (2009): Wie deutsch sind Russlanddeutsche? Eine empirische Studie zur ethnischkulturellen Identität in russlanddeutschen Aussiedlerfamilien Waxmann, Münster, Munich, Berlin.

KLAGGE, B.-KLEIN-HiTPAß, K. (2010): High-skilled return migration and knowledge-based economic development in Poland European Planning Studies 8 (10): 1631-1651. https://doi.org/10.1080/09654313.2010.504346

Regional Statistics, Vol. 8. No. 1. 2018: 3-28; DOI: 10.15196/RS080101 
Lachmayer, K.-BAuer, L. (ed.) (2008): Praxiswörterbuch Europarecht Springer Verlag, Berlin.

LAfleur, J. M.-STANEK, M. (eds.) (2017): South-North Migration of EU Citizens in Times of Crisis Imiscoe Research Series, Springer, Wiesbaden.

LitTLE, A.-VAUghan-Williams, N. (2017): Stopping Boats, saving lives, securing subjects: humanitarian borders in Europe and Australia European Journal of International Relations 23 (3): 533-556. https://doi.org/10.1177/1354066116661227

MARKOVA, E. (2010): Optimising migration effects: A perspective from Bulgaria In: Black, R.-Engbersen, G.-OKólski, M.-Pantîru, C. (eds.) A Continent Moving West? EU-Enlargement and Labour Migration from Central and Eastern Europe pp. 207-230, Amsterdam.

MaYer, M. M.-YAmamura, S.-Schneider, J.-Müller, A. (2012): Zuwanderung von internationalen Studierenden aus Drittstaaten Working Paper der Forschungsgruppe des Bundesamtes für Migration und Flüchtlinge 47., Nuremberg.

MAYR, K.-PERI, G. (2008): Return migration as a channel of brain gain NBER Working Paper No. 14039. Cambridge.

MeINARDUS, P. (2017): Recruiting from Spain - a qualitative insight into Spanish-German labor migration projects In: GLORIUS, B.-DomíngueZ-MujiCA, J. (eds.) European Mobility in Times of Crisis. The New Context of European South-North Mobility pp. 215-241, transcript, Bielefeld.

Morokvasic, M.-DE Tinguy, A. (1993): Between East and West: A new migratory space In: Rudolph, H. -Moroksvasic, M. (eds.) Bridging States and Markets. International Migration in the Early 1990s pp. 245-263, Berlin.

Müller, A. (2013): Die Organisation der Aufnahme und Unterbringung von Asylbewerbern in Deutschland Nuremberg.

NADler, R.-Kovacs, Z.-Glorius, B.-LANG, T. (2016): Return migration and regional development in Europe. Mobility against the stream. Palgrave McMillan, London.

Pilkington, E. (1988): Beyond the Mother Country: West Indians and the Notting Hill White Riots Tauris, London.

SACHVERSTÄNDIGENRAT DEUTSCHER STIFTUNGEN FÜR INTEGRATION UND MIGRATION (SVR) (2013): Erfolgsfall Europa? Folgen und Herausforderungen der EUFreizügigkeit für Deutschland. Jahresgutachten 2013 mit Migrationsbarometer Berlin.

SCHAder StifTung (HrsG.) (2011): Integrationspotenziale in kleinen Städten und Landkreisen. Ergebnisse des Forschungs-Praxis-Projekts Darmstadt.

SCHADER STIFTUNG (HRsG.) (2013): Potenzialbericht. Erste Ergebnisse der Erhebungen vor Ort. Forschungs-Praxis-Projekt: Integrationspotenziale ländlicher Regionen im Strukturwandel Darmstadt.

Solomos, J. (1993): Race and Racism in Britain Palgrave Macmillan, London.

StATISTISCHES Bundesamt (2015): Bevölkerung Deutschlands bis 2060. 13. Koordinierte Bevölkerungsvorausberechnung Wiesbaden.

STEIZ, D. (2011): Vertraute Fremdheit - fremde Heimat. Deutsche Sprache und soziale Integration russlanddeutscher Spätaussiedler in Geschichte und Gegenwart Tectum Verlag, Marburg.

Regional Statistics, Vol. 8. No. 1. 2018: 3-28; DOI: 10.15196/RS080101 
TEICHLER, U.-JAnson, K. (2007): The professional value of temporary study abroad in another European country: Employment and work of former Erasmus students Journal of Studies in International Education 11 (3-4): 486-495. https://doi.org/10.1177/1028315307303230

VAN DE KAA, D. J. (1987): Europe's second demographic transition Population Bulletin $42(1): 1-57$

VAN DE KAA, D. J. (2001): Postmodern fertility preferences: from changing value orientation to new behavior Population and Development Review 27: 290-331.

WolfeIL, N. (2013): Translators of knowledge? Labour market positioning of young Poles returning from studies abroad in Germany. In: GLORIUS, B.-GRABOWSKALusinskA, I.-KuviK, A. (eds.) Mobility in Transition. Migration Patterns after EU-Enlargement, Amsterdam, 259-276.

Worbs, S.-Bund, E.-Kohls, M.-BABKA VOn Gostomski, C. (2013): (Spät-) Aussiedler in Deutschland. Eine Analyse aktueller Daten und Forschungsergebnisse. Forschungsbericht 20. Nuremberg: Bundesamt für Migration und Flüchtlinge.

ZEIT ONLINE 10.10.2015: Warten auf "Aktenanlage" verlängert Asylverfahren http://www.zeit.de/politik/deutschland/2015-10/asylverfahren-fluechtlingebamf-erstaufnahme (downloaded: 14.09.2016) 